\title{
Health consequences of thick forest fire smoke to healthy residents in Riau, Indonesia: a cross-sectional study
}

Jamal Zaini, Agus Dwi Susanto, Erlang Samoedro, Vonni Christiana Bionika, Budhi Antariksa

Check for updates

pISSN: 0853-1773 • elSSN: 2252-8083 https://doi.org/10.13181/mji.oa.204321 Med J Indones. 2020;29:58-63

Received: November 12, 2019 Accepted: February 10, 2020

Authors' affiliations:

Department of Pulmonology and Respiratory Medicine, Faculty of Medicine, Universitas Indonesia, Persahabatan National Respiratory Hospital, Jakarta, Indonesia

Corresponding author:

Jamal Zaini

Department of Pulmonology and Respiratory Medicine, Faculty of Medicine, Universitas Indonesia, Persahabatan National Respiratory Hospital, Jalan Persahabatan Raya No.

1, Rawamangun, East Jakarta 13230, DKI Jakarta, Indonesia

Tel/Fax: +62-21-4893536

E-mail: jamal.zaini@gmail.com

\begin{abstract}
BACKGROUND Indonesia forest fire in 2015 emitted a huge amount of pollutants into the air. This study was aimed to assess the health consequences of forest fire smoke in healthy residents in Riau during forest fire disaster in 2015.
\end{abstract}

METHODS This cross-sectional study was performed in healthy residents who lived in Pekanbaru, Riau Province, Sumatera, for at least 6 months during forest fire disaster in 2015, and data were taken in October 2015. Questionnaires consisting of respiratory and non-respiratory symptoms were collected. Lung function was assessed by spirometry (MIR II Spirolab ${ }^{T M}$ spirometer, Medical International Research, Italy) and exhaled carbon monoxide ( $\mathrm{CO}$ ) was assessed using piCO+ Smokerlyzer ${ }^{\circledR}$. Heart rate at rest and oxygen saturation in the room air were measured using Onyx 9591 Pulse Oximeter ${ }^{\circledR}$.

RESULTS A total of 89 subjects were mostly female (75.3\%), housewife (37.7\%), nonsmoker $(86.5 \%$ ) with mean age of 38.9 years old. The non-respiratory and respiratory symptoms were reported in $84.7 \%$ and $71.4 \%$ subjects, respectively. Lung function was impaired in $72.6 \%$ subjects, mostly with mild obstruction and mild restriction. Exhaled CO was highly detected over normal values (mean [standard deviation] = 32.6 [9.97] ppm) with predicted carboxyhemoglobin ( $\mathrm{COHb})$ of $5.74(1.56)$.

CONCLUSIONS Forest fire smoke exposure increased the respiratory and nonrespiratory symptoms among healthy individuals, which showed impairment in lung function, exhaled $\mathrm{CO}$, and predicted $\mathrm{COHb}$. Long term health effects on healthy individuals exposed to forest fire smoke warrant further evaluation.

KEYWORDS carbon monoxide, exhalation, forest fire, Indonesia, lung function
According to the World Bank Report 2016, around 2.6 million hectares of land in Indonesia, an area size of 4.5 times Bali Island, were burned during June and October 2015. The burned area was mainly peatland with mixed vegetation, including rainforests, palm oil plantations, and bushes. ${ }^{1}$ The World Bank estimates that the 2015 forest fire disaster in Indonesia cost the country at least USD 16.1 billion (IDR 221 trillion), which is equivalent to $1.9 \%$ of its 2015 gross domestic product (GDP). In the same year, agriculture and forestry sustained estimated losses and damages of USD 8.8 billion (IDR 120 trillion). Substantial costs to the environment, which made up $26 \%$ of the total losses, included losses to biodiversity and ecosystem services. Haze also forced school closures for up to 34 days, resulting in USD 34 million in costs. The worst of the fires in October 2015 impacted 24,773 schools' closure and 4,692,537 students. ${ }^{1}$

Forest fire smoke emits vast amounts of air pollutants of varying diameters into the air; of these

Copyright @ 2020 Authors. This is an open access article distributed under the terms of the Creative Commons Attribution-NonCommercial 4.0 International License (http:// creativecommons.org/licenses/by-nc/4.0/), which permits unrestricted non-commercial use, distribution, and reproduction in any medium, provided the original author and source are properly cited. For commercial use of this work, please see our terms at https://mji.ui.ac.id/journal/index.php/mji/copyright. 
pollutants, particles of PM2.5 and PM10 are the most hazardous because of their adverse effect on human health. ${ }^{2}$ Existing research suggests that long term exposure to air pollutants increased cardiovascular, chronic respiratory, and neurological diseases. ${ }^{3}$ Air pollution also correlates with the higher risk of mortality and morbidity among children. A study on the effects of the 1998 Indonesian forest fire haze on fetal, infant, and under-three child mortality showed that air pollution led to 15,600 fewer surviving children. ${ }^{4}$ Another study showed that children exposed to the fire smoke are shorter on average 3 years post-exposure and had lower lung capacity 10 year post-exposure. ${ }^{5}$ Data on direct and acute effects on respiratory symptoms and lung function at the time of the forest fire disaster among healthy residents are scarce because carrying out relevant studies in the middle of such disasters is extremely difficult. Given this background, this study was aimed to assess acute symptoms and lung function among residents exposed to heavy smoke during the forest fire disaster in Riau, Sumatra, in 2015.

\section{METHODS}

This study was a cross-sectional study to assess symptoms and lung function among healthy subjects exposed to forest fire smoke during the forest fire disaster in 2015 in Pekanbaru, Riau Province. Riau Province in Sumatera, Indonesia was among the worst area affected by the forest fire based on Indonesia National Institute of Aeronautics and Space satellite data in 2015 (Figure 1).

Pekanbaru was selected as the study site because this city is among the most seriously affected by the fires could be accessed within 7-8 hours by car from Padang Airport during the disaster. Based on Indonesian Meteorological, Climatological, and Geophysical Agency, the air quality index during the study period was hazardous (numerical value, 357) and visibility was $<500 \mathrm{~m}$.

Two primary health centers were chosen in Pekanbaru due to accessibility during the disaster (Melur and Simpang Tiga). Healthy adult residents who lived around two primary health centers in Pekanbaru, Riau were consecutively recruited on October 23-24, 2015. To qualify for this study, subjects must have been living in Pekanbaru for a minimum of 6 months of which forest fire disaster happened. Moreover, the subjects must not have any chronic illness, such as diabetes mellitus, chronic kidney disease, congestive heart failure, or cancer as determined by anamnesis and physical examination.

The subjects were interviewed using the Indonesian version of the American Thoracic Society (ATS) respiratory questionnaire. Additional information regarding non-respiratory symptoms and personal protective equipment use during smoke exposure were also obtained. Face mask usage was classified as "always" if respondent wear it more than 4 days in a week, otherwise it will be classified as "rare". ${ }^{6}$ Those who always wear face mask will be asked further for the type of mask and the time of using it. Spirometry was performed using MIR II Spirolab ${ }^{\text {TM }}$ spirometer (Medical International Research, Italy) that had been calibrated before the procedure. Spirometry values were taken a minimum of 3 times to ensure acceptable and reproducible results based on ATS guidelines. ${ }^{7}$ Forced vital capacity (FVC), forced expiratory volume
Figure 1. Forest fire hotspots during October 2015 forest fire disaster in Indonesia (source: http://modis-catalog. lapan.go.id/monitoring/)

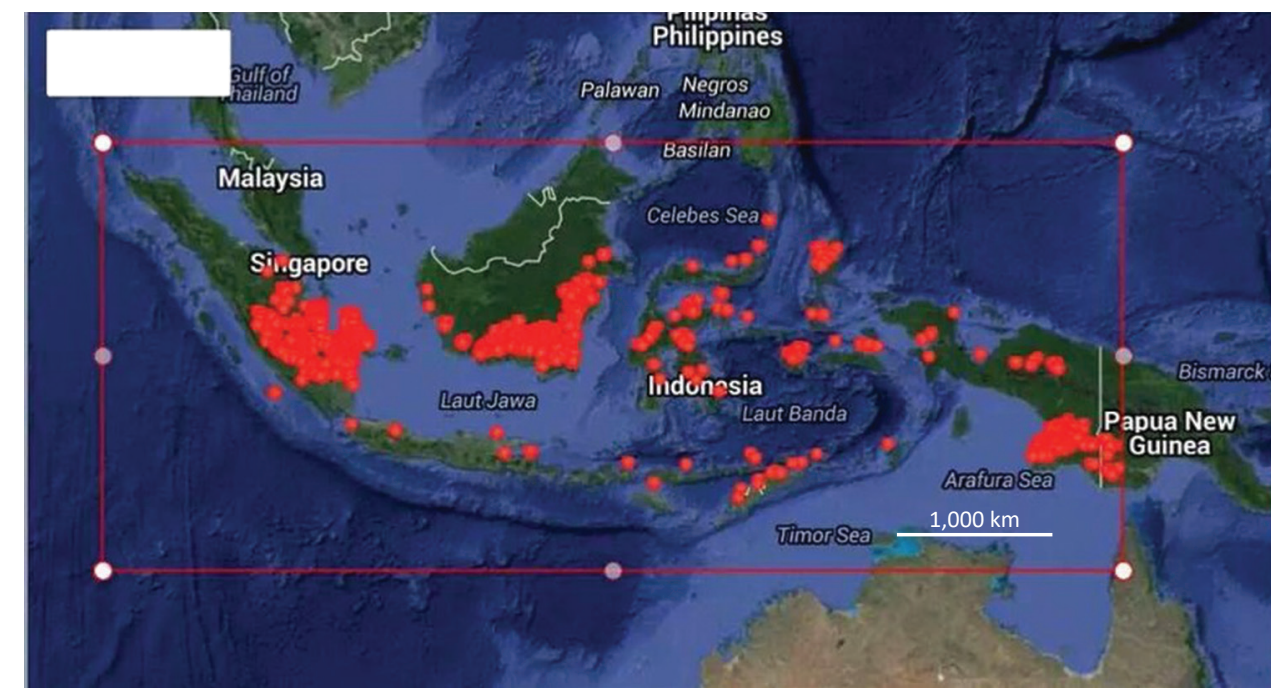


Table 1. Demographics, symptoms, and protective equipment use of respondents

\begin{tabular}{|c|c|}
\hline Characteristics & $\mathrm{n}(\%), \mathrm{N}=89$ \\
\hline Female sex & $67(75.3)$ \\
\hline Age (years), mean (SD) & $38.9(11.5)$ \\
\hline Non-smoker & $77(86.5)$ \\
\hline \multicolumn{2}{|l|}{ Occupations } \\
\hline Student & $6(6.7)$ \\
\hline Housewife & $33(37.1)$ \\
\hline Farmer & $11(12.4)$ \\
\hline Indoor worker & $39(43.8)$ \\
\hline Respiratory symptoms & $70(71.4)$ \\
\hline Cough & $28(28.6)$ \\
\hline Wheeze & $1(1)$ \\
\hline Phlegm & $5(5.1)$ \\
\hline Cough+wheeze & $6(6.1)$ \\
\hline Cough+phlegm & $21(21.4)$ \\
\hline Non-respiratory symptoms & $83(84.7)$ \\
\hline Eye symptoms & $40(40.8)$ \\
\hline Headache & $40(40.8)$ \\
\hline Tinnitus & $2(2.1)$ \\
\hline Gl tract symptoms & $12(12.2)$ \\
\hline Skin symptoms & $3(3.1)$ \\
\hline \multicolumn{2}{|c|}{ Type and time of protective equipment use } \\
\hline \multicolumn{2}{|l|}{ Frequency of mask usage } \\
\hline Always & $85(95.5)$ \\
\hline Rarely & $4(4.5)$ \\
\hline \multicolumn{2}{|l|}{ Types of mask* $(n=85)$} \\
\hline Cotton-type mask & $16(18.8)$ \\
\hline Surgical mask & $57(67.1)$ \\
\hline N95 & $12(14.1)$ \\
\hline \multicolumn{2}{|l|}{ Time of using mask* $(n=84)$} \\
\hline Anytime (at home and outside) & $8(9.4)$ \\
\hline During activities outside & $72(84.8)$ \\
\hline During commuting to work & $4(4.8)$ \\
\hline
\end{tabular}

$\mathrm{SD}=$ standard deviation; $\mathrm{Gl}=$ gastrointestinal

*The type of mask and the time of using it (missing data $=1$ ) were asked to those who always using face mask group

in 1 second $\left(\mathrm{FEV}_{1}\right)$, and $\mathrm{FEV}_{1} / \mathrm{FVC}$ ratio were measured. Predicted $\mathrm{FEV}_{1}\left(\mathrm{FEV}_{1} \%\right)$ and (FVC\%) FVC values were calculated based on the Indonesia Pneumomobile Project which is suited to the Indonesian population. ${ }^{8}$ The result of the spirometry was classified as "restrictive" if FVC measured/FVC predicted $<80 \%$. and "obstructive" if $\mathrm{FEVI} / \mathrm{FVC}<80 \%$. Exhaled carbon monoxide (exCO) was measured using piCO+
Table 2. Lung function among healthy residents exposed to forest fire smoke

\begin{tabular}{|lc|}
\hline Lung function & $\mathrm{n}(\%), \mathrm{N}=62$ \\
\hline Spirometry results & $17(27.4)$ \\
\hline Normal & $45(72.6)$ \\
\hline Not normal/decreased & $9(30.6)$ \\
\hline Restrictive (mild) & $15(24.2)$ \\
\hline Obstructive (mild) & $11(17.7)$ \\
\hline Mixed (obstructive + restrictive) & $32.6(9.97)$ \\
\hline Exhale CO (ppm), mean (SD) & $45.08(8.76)$ \\
\hline Smoker ( $n=9)$ & $30.19(5.77)$ \\
\hline Non-smoker $(n=53)$ & $5.74(1.56)$ \\
\hline COHb (\% predicted), mean (SD) & $7.71(1.54)$ \\
\hline Smoker $(n=9)$ & $5.4(1.02)$ \\
\hline Non-smoker $(n=53)$ & $97.81(1.36)$ \\
\hline SpOz, mean (SD) & $86.03(14.61)$ \\
\hline Heart rate, mean (SD)
\end{tabular}

$\mathrm{CO}=$ carbon monoxide; $\mathrm{COHb}=$ carboxyhemoglobin; $\mathrm{SpO}_{2}=$ saturation level of oxygen

Smokerlyzer ${ }^{\circledR}$ (Bedfont Scientific Ltd, United Kingdom) according to the manufacturer's instruction. Briefly, breaths were held for $10 \mathrm{sec}$ during exCO measurement. Predicted carboxyhemoglobin ( $\mathrm{COHb})$ was calculated based on exCO value. Pulse oximetry (Onyx 9591 Pulse Oximeter ${ }^{\circledR}$, Nonin Medical B.V, The Netherlands) was measured before spirometry, procedure and heart rates at rest and oxygen saturation in room air were recordd. This study was approved by the Ethics Committee of the Faculty of Medicine, Universitas Indonesia (No: 10/ UN2.F1/ETIK/2016).

\section{RESULTS}

One hundred subjects who lived near the health centers were asked to participate in the study. Eleven subjects did not complete the initial screening and refused to participate.

A total of 89 residents with mean (standard deviation) age of 38.9 (11.5) years were included in the analysis. All subjects had been living in Pekanbaru, Riau, for over 3 years and stayed in the city during the forest fire disaster in 2015 . They were mostly female (75.3\%), non-smoker (86.5\%), and housewife (37.7\%) as shown in Table 1.

Respiratory symptoms were present in $71.4 \%$ of the sample (70 subjects). Non-respiratory symptoms, such as eye rash/irritation, urticaria/itching, gastrointestinal 
(GI) tract issues (diarrhea, nausea), headache, and tinnitus, were also reported by $84.7 \%$ of the subjects. Most of the subjects wore protective equipment, usually during outdoor activities, with surgical mask being the most frequent type of protective equipment.

Among 89 subjects, 62 subjects agreed and were able to perform spirometry in accordance with ATS guideline and exCO measurement (Table 2).

Lung function was lower in smoker $(n=9)$ than in non-smoker $(\mathrm{n}=53)$ in terms of $\mathrm{FEV}_{1} \%$ (64.7 versus $70.9 \%$ ); FVC\% (78.2 versus $80 \%$ ); FEV 1 /FVC (70 versus $75 \%$ ). ExCO and predicted $\mathrm{COHb}$ were also higher in smokers (45.08 ppm exCO and $7.71 \%$ predicted $\mathrm{COHb}$ ) than nonsmokers (30.19 $\mathrm{ppm}$ exCO, 5.4\% predicted $\mathrm{COHb}$ ).

\section{DISCUSSION}

There were limited data regarding health effect during the 2015 forest fire disaster in Indonesia, especially in healthy population, and most of the related studies were conducted in neighboring but otherwise far areas, such as Malaysia and Singapore. ${ }^{9}$ This study was done in Pekanbaru, Riau Province, Sumatera, one of the cities most heavily exposed to forest fire smoke in October 2015. Based on the Indonesian Meteorological, Climatological, and Geophysical Agency, the air quality index during this study was hazardous (numerical value, 357) and visibility was $<500 \mathrm{~m}$ during the study period. The city airport was shut down, and the area could only be accessed via an 8-12-hour trip by car from the nearest other city airport.

Of 89 subjects recruited in this study, most were female $(74.1 \%)$, housewife (37.0\%), indoor workers $(43.8 \%)$, and non-smoker (84.0\%) with a mean age of 39.8 years. This population represented one of the groups most prone to health effects from forest fire smoke disasters. During the disaster, this population was heavily exposed to forest fire smoke both indoors and outdoors and could not move to less-polluted areas. Smoking was less prevalent among the subjects because most of the population was female. This study was compatible with the Global Adult Tobacco Survey 2011, which showed that less than $5 \%$ of Indonesian females are smokers compared with $67 \%$ of Indonesian males. ${ }^{10}$

Based on the questionnaire, respiratory symptoms were reported by $71.4 \%$ and surprisingly non-respiratory symptoms, such as eyerash/irritation, urticaria/itching, Gl tract issues (diarrhea, nausea), headache, and tinnitus, were also reported by $84.7 \%$ of the subjects. Forest fire smoke constitutes molecules less than 10 $\mu \mathrm{m}$ in diameter and could induce inflammation of the respiratory tract. Smog may also induce non-respiratory symptoms, such as eye irritation and $\mathrm{Gl}$ tract symptoms through water contamination. ${ }^{11}$ According to a study in Jambi, Sumatera, by a Japanese team during forest fire in $1998,{ }^{12}$ forest fire smoke contains large amounts of hydrocarbon derivatives, such as benzopyrenes, which may cause not just airway irritation but also skin and eye irritation and cancer. ${ }^{13}$ Knowledge of the chemicals that make up forest fire smoke is useful to understand the potential effects of forest fires on human health. Relevant measurements may be conducted as part of mitigation during disaster in the future.

Study evaluating the lung function in normal individuals exposed to heavy forest fire smoke are rare. In this study, we found $72.6 \%$ of the sample reported disturbances in lung function in the form of mild obstructive and mild restrictive patterns. The high proportion of subjects with impaired lung function reveals the acute effect of heavy smoke on normal lungs. These effects may increase in highly prone individuals, such as asthmatics or chronic obstructive lung disease patients. Kunii et al ${ }^{12}$ found that $68 \%$ of the study subjects, had a decreased in lung function in the study subject, including those with other respiratory diseases and the elderly, developed decreases in lung function after the 1998 forest fire disaster. A study of active firefighters indicated that lung function decreases on duty but returned to baseline levels off duty. ${ }^{12,13}$ Cohort study related to lung function should be done to determine the extent of chronic forest fire smoke exposure in this population.

One of the parameters to show the air quality inhale into the respiratory system was exCO measurement and routinely done for smoking cessation program. ${ }^{14}$ The reference value of exCO in normal healthy nonsmoker is <4 ppm; for smokers, it is set at $15-17 \mathrm{ppm} .{ }^{16}$ In this study, exCO was very high, even among healthy subjects who did not smoke. The mean exCO was 32.6 ppm, which is 7.5 times higher above normal levels. The exCO of smokers (45.08 ppm) was higher than that of non-smokers (30.19 ppm); both levels are much higher compared with the baseline exCO of smokers. $\mathrm{CO}$ binds to hemoglobin to form $\mathrm{COHb}$, which reduces the ability of hemoglobin molecules to bind $\mathrm{O}_{2}$ and could potentially induce tissue hypoxia. ${ }^{17,18}$ Thus, $\mathrm{CO}$ in the air correlates directly with $\mathrm{COHb}$ levels. Based 
on the predicted/calculated $\mathrm{COHb}$ values, the subject has increased predicted $\mathrm{COHb}$ in the body with $5.74 \%$ of $\mathrm{COHb}$ during exposure to the forest fire may be observed at $5 \% \mathrm{COHb}$, and $16 \% \mathrm{COHb}$ could induce headache. The lethal effect could be seen in $40 \% \mathrm{COHb} .{ }^{17}$ Individual with heart disease, children, and pregnant women are especially susceptible to high $\mathrm{COHb}$. For example, $5 \% \mathrm{COHb}$ could induce arrhythmia and angina in individuals with coronary arterial disease, and 5-7\% $\mathrm{COHb}$ could induce nausea, headache, and lethargy in children. The acute effect of $>13 \% \mathrm{COHb}$ induce stillbirth in pregnant women. ${ }^{17,18}$ In this study, 40\% of subjects reported headache. While the causative etiology of this effect must be further elucidated, chronic exposure to $\mathrm{CO}$ may contribute to the symptom. Long-term effects related to chronic high $\mathrm{CO}$ exposure in this population must be studied further.

Use of protective masks prevents inhalation of pollutants into the lungs. ${ }^{19,20}$ This study also evaluated the practice of using protective masks during the disaster and found $95.5 \%$ of participants using the protective mask during the disaster, especially when carrying out outdoor activities. However, only $14.1 \%$ of the respondents reported using N95 masks, mainly because these masks are not widely available and uncomfortable. The reasons for those were $\mathrm{N} 95$ mask not widely available and less comfortable. Information on the correct and appropriate use of personal protective equipment during forest fire smoke exposure should be included in the educational programs for this population. N95 masks should also be provided by the government if possible.

There are some limitation of this study. It was done during the peak of forest fire disaster in 2015 of which access to the area was limited only by land/car and some residents moved to safer and better air quality out of Pekanbaru, Riau Province, Sumatera. There was no data regarding the chemical components of polluted air nor details of various air quality parameters during the study period. Whether the observed permanent lung dysfunction is unknown because the present study design is crosssectional and the assessments were conducted only once. Regarding $\mathrm{COHb}$, it is ideally measured in the blood, but in this study, we calculate the predicted $\mathrm{COHb}$ values from exCO since it was not feasible. Nevertheless, this study reveals the effects of forest fire smoke exposure on a common group who are prone to health risks from such exposure. The data also reflect the baseline acute effect of forest fire smoke exposure on this group.

In conclusion, forest fire smoke exposure increases respiratory and non-respiratory symptoms among healthy individuals even when personal protective equipment is used during the fire. Acute respiratory symptoms include increased exhale $\mathrm{CO}$, increased predicted $\mathrm{COHb}$, and reduced lung function (obstructive and restrictive pattern). Long-term health effects not only on the respiratory system but also other organ systems warrant further evaluation.

\section{Conflicts of Interest}

The authors affirm no conflict of interest in this study.

\section{Acknowledgment}

The authors would like to thank the Ministry of Health IndonesiaHaze Hazard Team for facilitating access to the affected area during 2015 forest fire disaster.

\section{Funding Sources}

This study was supported by Departement of Pulmonology and Respiratory Medicine, Faculty of Medicine, Universitas Indonesia. The supporting source had no involvement into nor influence on the content of the manuscript.

\section{REFERENCES}

1. World Bank Group. Indonesia Sustainable Landscape Knowledge Note: 1. The cost of fire, an economic analysis of Indonesia's 2015 fire crisis. Jakarta: The World Bank. 2016. p. 1-9.

2. Utah Physicians for a Healthy Environment. 2015 report on the health consequences of wood smoke. Utah: Utah Physicians for a Healthy Environment. 2015. p. 1-32.

3. World Health Organization. Review of evidence on health aspects of air pollution: REVIHAAP project technical report. Copenhagen: World Health Organization, Regional Office for Europe; 2013. p. 1-132.

4. Jayachandran S. Air quality and early-life mortality: evidence from Indonesia's wildfires. Cambridge: National Bureau of Economic Research Working Paper 14011. 2008. p. 1-50.

5. Rosales-Rueda M, Triyana M. The persistent effects of early-life exposure to air pollution: evidence from the Indonesian forest fires. J Human Resources. 2018;54(4):1037-80.

6. Wheeler K, McKelvey W, Thorpe L, Perrin M, Cone J. Asthma diagnosed after 11 September 2001 among rescue and recovery workers: finding from the World Trade Centre Health Registry. Environ Health Perpect 2007;115:1584-90.

7. Miller MR, Hankinson J, Brusasco V, Burgos F, Casaburi R, Coates A, et al. Standardization of spirometry. Eur Respir J. 2005;26:319-38.

8. Alsagaff $\mathrm{H}$, Mangunnegoro $\mathrm{H}$. Reference spirometric values of healthy Indonesian Schoolchildren and working adults, using equipment and methods that meet ATS 1987 recommendations, The Indonesian Pneumomobile Project. Surabaya: Airlangga University Press; 1993. Indonesian.

9. P Crippa S, Castruccio S, Archer-Nicholls S, Lebron GB, Kuwata $M$, Thota $A$, et al. Population exposure to hazardous air quality due to 2015 fire in Equatorial Asia. Sci Rep. 2016;6:37074.

10. World Health Organization. Global adult tobacco survey: Indonesia report 2011. Jakarta: World Health Organization, Regional Office for South East Asia; 2012. p. 1-162.

11. Swiston JR, Davidson W, Attridge S, Li GT, Brauer M, van Eeden 
SF. Wood smoke exposure induces a pulmonary and systemic inflamatory response in firefighers. Eur Respir J. 2008;32(1):12938.

12. Kunii O, Kanagawa S, Yajima I, Hisamatsu Y, Yamamura S, Amagai T, et al. The 1997 haze disaster in Indonesia: its air quality and health effects. Arch Environ Health. 2002;57(1):16-22.

13. World Health Organization. Polycyclic aromatic hydrocarbons (PAHs). Chapter 5.9. Copenhagen: World Health Organization, Regional Office for Europe; 2000. p. 1-24.

14. Adetona O, Hall DB, Naeher LP. Lung function changes in wildland firefighters working at prescribed burns. Inhal Toxicol. 2011;23(13):835-41.

15. Slattery F, Johnston K, Paquet C, Bennett H, Crockett A. The long-term rate of change in lung function in urban professional firefighters: a systematic review. BMC Pulm Med. 2018;18(1):149.

16. Deveci SE, Deveci F, Açik Y, Ozan AT. The measurement of exhaled carbon monoxide in healthy smokers and non-smokers. Respir Med. 2004;98(6):551-6.

17. Griem P, Rodgers G, Iris Camacho I. Carbonmonoxide. In: National Research Council. Acute exposure guideline levels for selected airborne chemicals. Washington DC: The National Academies Press: 2010. Vol. 8. p. 49-142.

18. World Health Organization. Air quality guidelines for Europe. 2nd ed. Copenhagen: World Health Organization, Regional Office for Europe; 2000. p. 1-273.

19. Adetona O, Simpson CD, Onstad G, Naeher LP. Exposure of wildland firefighters to carbon monoxide, fine particles and levoglucosan. Ann Occup Hyg. 2013;57(8);979-91.

20. Susanto DA, Nawas A, Samoedro E, Zaini J, Yunus F, Fitriani F, et al. Prevention and management of health impacts from smoke from forest fires. Jakarta: Universitas Indonesia; 2015. p. 4-11. Indonesian. 